\title{
Dinuclear thiazolylidene copper complex as highly active catalyst for azid-alkyne cycloadditions
}

\author{
Anne L. Schöffler, Ata Makarem, Frank Rominger and Bernd F. Straub*
}

\author{
Full Research Paper \\ Address: \\ Organisch-Chemisches Institut, Universität Heidelberg, Im \\ Neuenheimer Feld 270, D-69120 Heidelberg, Germany \\ Email: \\ Bernd F. Straub* - straub@oci.uni-heidelberg.de \\ * Corresponding author \\ Keywords: \\ catalysis; click; copper; CuAAC; $N$-heterocyclic carbene; thiazole
}

Beilstein J. Org. Chem. 2016, 12, 1566-1572.

doi:10.3762/bjoc. 12.151

Received: 02 April 2016

Accepted: 28 June 2016

Published: 21 July 2016

This article is part of the Thematic Series "Organometallic chemistry". In memoriam Prof. Dr. Peter Hofmann.

Guest Editor: L. Gade

( 2016 Schöffler et al.; licensee Beilstein-Institut.

License and terms: see end of document.

\begin{abstract}
A dinuclear $N$-heterocyclic carbene (NHC) copper complex efficiently catalyzes azide-alkyne cycloaddition (CuAAC) "click" reactions. The ancillary ligand comprises two 4,5-dimethyl-1,3-thiazol-2-ylidene units and an ethylene linker. The three-step preparation of the complex from commercially available starting compounds is more straightforward and cost-efficient than that of the previously described 1,2,4-triazol-5-ylidene derivatives. Kinetic experiments revealed its high catalytic CuAAC activity in organic solvents at room temperature. The activity increases upon addition of acetic acid, particularly for more acidic alkyne substrates. The modular catalyst design renders possible the exchange of $N$-heterocyclic carbene, linker, sacrificial ligand, and counter ion.
\end{abstract}

\section{Introduction}

The copper-catalyzed azide-alkyne cycloaddition (CuAAC) is one of the most important "click" reactions for the facile covalent linking of two molecules [1-3]. In 2002, the research groups of Meldal and Sharpless independently discovered the strongly rate-enhancing effect of copper(I) salts for azide-alkyne cycloadditions. The 1,4-disubstituted 1,2,3-triazoles are formed exclusively with essentially quantitative conversion and under mild reaction conditions [4-6]. The $\mathrm{CuAAC}$ reaction has found broad application in the preparation of peptide-conjugates [7,8], multicomponent syntheses [9], preparation of hydrogels, microgels and nanogels [10], (anion) supramolecular chemistry [11,12], in medicinal chemistry [13], therapeutics, biomaterials and bioactive surfaces [8,14], imaging of biochemical processes [15], localization of bioactive compounds inside living cells [16], syntheses of small-molecule screening libraries [17], catenane and rotaxane syntheses [18], in reactions under continuous flow processing [19], polymer and surface science [20-26], nucleoside, nucleotide, and oligonucleotide chemistry [27-29], in fluorogenic reactions [30], and in the syntheses of dendrimers [25,31]. The detailed mechanism of this reaction and the exact role of copper(I) and the species involved in the catalytic cycle had remained unclear for many years. The first proposals for the mechanism suggested the participation of only one copper(I) atom in the key 
elementary steps. In 2005, Fokin and Finn determined the reaction rate of a CuAAC reaction to be second order in the concentration of copper [32]. Since then, the understanding of the mandatory role of dinuclear copper complexes as catalyst intermediates has vastly improved (Scheme 1) [33-37]. In 2013, the Fokin group provided evidence for the dicopper pathway of CuAAC reactions by a series of kinetic and isotopic labeling studies [34]. In 2015, the Bertrand group prepared, isolated, and structurally characterized molecular dicopper acetylide complexes, and investigated their reactivity towards azide substrates [36].

For standard CuAAC reactions, copper(I) carboxylates [5,38], mononuclear copper(I) phosphine carboxylate complexes [39] or copper(I) salts are an ideal compromise of low catalyst cost and high catalyst activity. However, CuAAC reactions of some substrates are not compatible with heterogeneous catalysis at the surface of insoluble copper(I) compounds. Instead, they depend on highly active molecular catalysts under homogeneous reaction conditions. Our research group has already established molecularly defined dicopper catalysts with unprecedented activity under diluted conditions with low catalyst loading $[37,40]$. Thus, we aimed at an even more facile synthesis of dicopper complexes with bis- $N$-heterocyclic carbene ancillary ligands.

\section{Results and Discussion}

We herein report the synthesis of an ethylene-linked bisthiazol2-ylidene dicopper(I) complex 2 that features high catalytic activity in CuAAC reactions. The advantage of this new complex
2 in comparison to dicopper complexes previously described by our research group [40] is its less time-consuming and more cost-efficient synthesis. Commercially available, inexpensive 4,5-dimethylthiazole is used as azole starting material instead of 4-aryl-1,2,4-triazoles. The precursor 1a for the NHC ancillary ligand is synthesized via a double $\mathrm{S}_{\mathrm{N}} 2$-reaction of two equivalents of thiazole derivative with 1,2-dibromoethane. In order to avoid the presence of halide ions as inhibitory ligands for copper(I) [2,41], bisthiazolium hexafluorophosphate $\mathbf{1 b}$ was obtained by a salt metathesis from bromide salt 1a with aqueous hexafluorophosphoric acid (Figure 1).

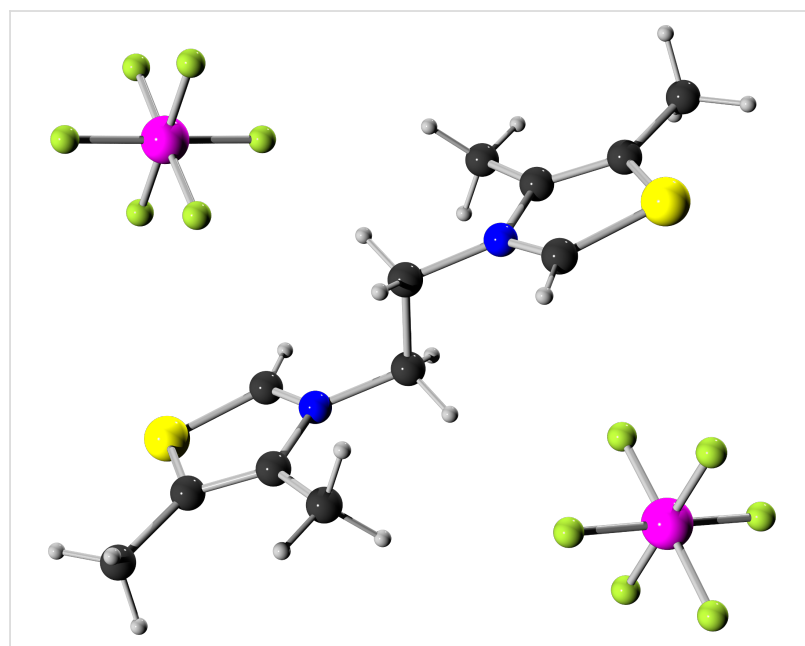

Figure 1: Ball-and-stick model $[42,43]$ of a single crystal X-ray structure of hexafluorophosphate salt 1b (CCDC 1472789). Color code: black carbon, grey hydrogen, yellow sulfur, blue nitrogen, magenta phosphorus, green fluorine.

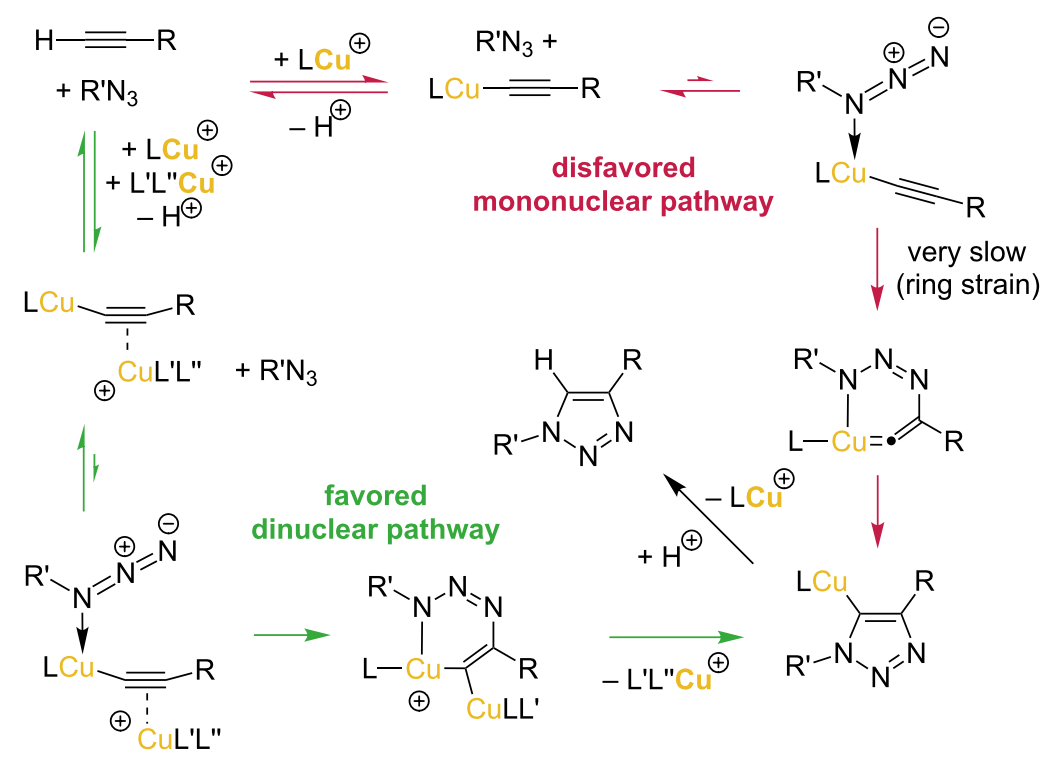

Scheme 1: Disfavored mononuclear pathway and favored dinuclear pathway in the CuAAC click reaction, according to the mechanistic proposal of reference [37]. R, R' = alkyl, aryl, silyl, carbonyl groups; L = NHC; L' = NHC or solvent; L" = solvent, acetylide, carboxylate, halide. 


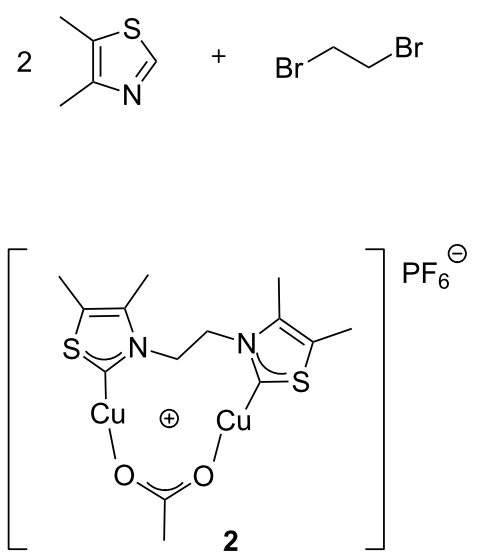
neat, $115^{\circ} \mathrm{C}, 3 \mathrm{~d}$
$86 \%$

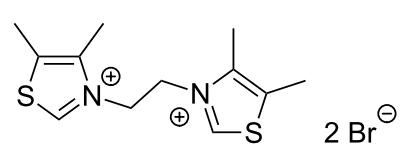

1a
1) $\mathrm{NaOAc}(2.3$ equiv)
2) $\mathrm{CuOAc}(2.2$ equiv)

THF, $\mathrm{N}_{2}, \mathrm{rt}, 5 \mathrm{~d}$ $86 \%$

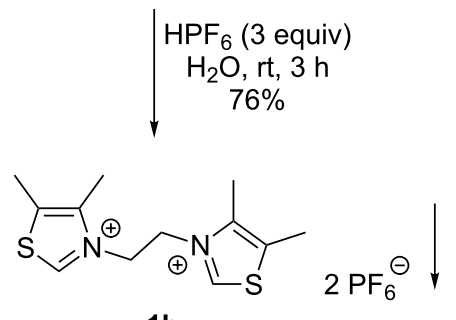

$1 b$

Scheme 2: Synthesis of dinuclear copper complex 2.

The final step is the reaction with copper(I) acetate and sodium acetate as additional base in order to deprotonate the thiazolium salt $\mathbf{1 b}$ and to form the bisthiazolylidene copper(I) complex 2. Due to the relatively high acidity of the thiazolium precursor ( $\mathrm{p} K_{\mathrm{a}} \approx 18$ [44]), a weak base such as sodium acetate yields small equilibrium concentrations of thiazol-2-ylidene. The latter then irreversibly binds to copper(I) ions (Scheme 2). The structure of the resulting complex $\mathbf{2}$ is presumably similar to the previously reported dinuclear bis(1,2,4-triazol-5-ylidene)copper(I) complexes that had been synthesized, characterized, and structurally characterized in our group [40]. The similarity of NMRspectroscopic data of the 1,2,4-triazol-5-ylidene and the 1,3thiazol-2-ylidene dicopper complex indicate that the complexes of both NHC ligand types consist of a bis-NHC ligand, two copper(I) ions and a labile acetate ligand that bridges the metal centers. The thiazolylidene complex $\mathbf{2}$ is air-stable in the solid state for at least several days. Stability tests in solution were taken under an atmosphere of nitrogen. Small amounts of a brown precipitate were formed in solution after one day. However, the NMR spectra showed no changes even after one week and in the presence of acetic acid. Therefore, we assume that complex $\mathbf{2}$ is quite robust against oxidization.

To test the catalytic performance of complex 2 with the help of continuous NMR spectroscopy, the reaction of benzyl azide with either phenylacetylene or ethyl propiolate in deuterated dichloromethane at room temperature was used (Table 1 and Figure 2). Due to the highly exothermic nature of the triazole formation, a high dilution of the reaction mixture and low catalyst loadings are necessary to prevent a thermal runaway. In order to compare the catalytic activity of complex 2 with conventional catalysts a kinetic study with copper(I) acetate was performed. All kinetic experiments were carried out under an atmosphere of nitrogen because of the air-sensitivity of complex 2 in solution (see Supporting Information File 1 for the detailed procedure).

Table 1: CuAAC reaction of benzyl azide and terminal alkynes with complex $\mathbf{2}$ or CuOAc as catalyst in absence or presence of added acetic acid

$$
\text { 舟 }
$$

\begin{tabular}{|c|c|c|c|c|}
\hline Entry & Alkyne & Catalyst & Additional HOAc & Half conversion time \\
\hline 1 & phenylacetylene & $1.8 \mathrm{~mol} \%$ complex 2 & - & $37 \mathrm{~min}$ \\
\hline 2 & phenylacetylene & $1.8 \mathrm{~mol} \%$ complex 2 & $9 \mathrm{~mol} \%$ & $22 \min$ \\
\hline 3 & phenylacetylene & CuOAc (homogeneous solution) & - & $166 \min$ \\
\hline 4 & ethyl propiolate & $0.9 \mathrm{~mol} \%$ complex 2 & - & $\approx 15 \mathrm{~h}^{*}$ \\
\hline 5 & ethyl propiolate & $0.9 \mathrm{~mol} \%$ complex 2 & $9 \mathrm{~mol} \%$ & $6 \min$ \\
\hline 6 & ethyl propiolate & CuOAc (homogeneous solution) & - & $\approx 19 \mathrm{~h}^{*}$ \\
\hline
\end{tabular}

*extrapolated half conversion time. 
The reaction with phenylacetylene and $1.8 \mathrm{~mol} \%$ copper complex 2 (Table 1, entries 1 and 2) reaches 50\% conversion within 37 min (without acetic acid, green triangles in Figure 2) and is slightly accelerated by addition of acetic acid (half conversion within $22 \mathrm{~min}$, blue dots). In contrast, the half conversion time for this reaction catalyzed by a saturated homogeneous solution of copper(I) acetate in deuterated dichloromethane is about $3 \mathrm{~h}$ (Table 1, entry 3, black dots in Figure 2). Therefore, the reaction with complex 2 is about 4.5 times (without HOAc) to 7.5 times (with HOAc) more effective compared to the homogeneous reaction with copper acetate. Under heterogeneous catalytic conditions, however, larger amounts of commercially available CuOAc powder with vivid stirring or shaking of the reaction mixture give rise to rapid CuAAC conversion. Thus, the molecular NHC dicopper catalyst complexes excel in homogeneous $\mathrm{CuAAC}$ reactions [40], while $\mathrm{CuOAc}$ excels in heterogeneous catalysis and in cost-effectiveness [38].

The reaction with ethyl propiolate in the presence of $0.9 \mathrm{~mol} \%$ catalyst is very slow with a half conversion time of more than nine hours (Table 1, entry 4, yellow diamonds). We attribute this poor catalytic activity to the formation of copper acetylide clusters or even coordination polymers. Analogous dicopper complexes of more sterically demanding bis-1,2,4-triazolylidene ancillary ligands are quantitatively converted to octacopper hexaacetylide clusters under the same conditions [37]. To date, we have not been able to characterize thiazolylidene copper acetylides. Addition of acetic acid greatly increases the rate of the $\mathrm{CuAAC}$ reaction with ethyl propiolate, so that half- conversion is reached after 6 min (Table 1 , entry 5, red squares). These observations are again consistent with the formation of a thermodynamically stable copper acetylide species [37], which are regenerated in the presence of acid to catalytically active dicopper acetylide intermediates [36]. The reaction catalyzed by copper acetate proceeds very slow. The extrapolated half-conversion is reached within approximately one day (Table 1 , entry 6 , grey triangles).

\section{Conclusion}

In summary, we have presented a molecularly defined bisthiazolylidene dicopper(I) complex that features high catalytic activity in CuAAC reactions. Its three-step synthesis is straightforward and cost-efficient. The modular design of this class of catalysts renders possible the tuning of the complex's properties and its features according to specific demands. Dicopper complexes with thiazolylidene ancillary ligands provide for improved availability, air-stability and convenience for the growing community of CuAAC users.

\section{Experimental \\ General methodology}

All reactions were carried out, unless described otherwise, under normal laboratory conditions under air. Reactions involving air-sensitive reagents were carried out in an atmosphere of argon using standard Schlenk techniques or in an MBraun LABmaster 130 glove box operated with nitrogen. Chemicals and solvents used in this work were supplied by the Department of Chemistry at the Ruprecht-Karls-University Heidel-

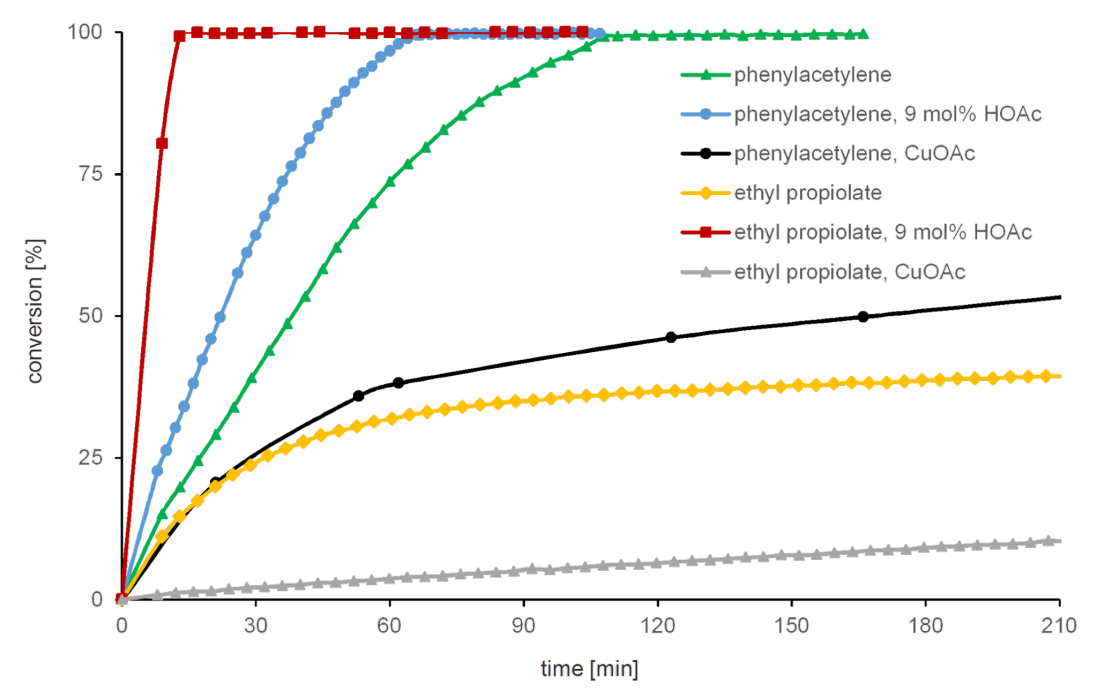

Figure 2: Time-conversion-diagram of the CuAAC reaction of benzyl azide with either phenylacetylene or ethyl propiolate in the presence of copper complex 2 ( $1.8 \mathrm{~mol} \%$ for reaction with phenylacetylene, $0.9 \mathrm{~mol} \%$ for reaction with ethyl propiolate) or in presence of CuOAc (saturated homogeneous solution) under an atmosphere of nitrogen in $\mathrm{CD}_{2} \mathrm{Cl}_{2}$ at rt (conversion referred to benzyl azide); reaction with phenylacetylene: green triangles (complex 2 without additional HOAc), blue dots (complex 2 in presence of 9 mol \% additional HOAc) and black dots (CuOAc solution); reaction with ethyl propiolate: yellow diamonds (complex 2 without additional HOAc), red squares (complex 2 in presence of 9 mol \% additional HOAc) and grey triangles (CuOAc solution). 
berg or bought directly from Acros Organics, Fisher Scientific, Sigma Aldrich, Strem Chemicals, and TCI. Anhydrous solvents were taken from an MBraun MB SCS-800 solvent purification system containing appropriate drying agents. Deuterated solvents for the use of NMR spectroscopy were obtained from Deutero GmbH and Euriso-Top.

${ }^{1} \mathrm{H}$ NMR spectra were recorded at room temperature and the following instruments were employed: Bruker ARX-250 (250 MHz), Bruker Avance 300 (300 MHz), Bruker Avance 400 (400 MHz), Bruker Avance 500 (500 MHz). Chemical shifts $\delta$ are indicated in ppm and were determined by reference to the residual ${ }^{1} \mathrm{H}$ solvent peaks (acetone: $2.05 \mathrm{ppm}$; chloroform: $7.26 \mathrm{ppm}$; dichloromethane: $5.32 \mathrm{ppm}$; DMSO: $2.50 \mathrm{ppm})$. Coupling constants $J$ are given in $\mathrm{Hz}$. The following abbreviations describe the observed multiplicities: $\mathrm{s}=$ singlet, $\mathrm{d}=$ doublet, $\mathrm{t}=$ triplet, $\mathrm{q}=$ quartet, quin $=$ quintet, sext $=$ sextet, sept $=$ septet, $\mathrm{m}=$ multiplet (composed abbreviations refer to multiple coupling patterns with the first letter indicating the greater coupling constant). ${ }^{13} \mathrm{C}\left\{{ }^{1} \mathrm{H}\right\}$ NMR spectra were recorded at room temperature with the following spectrometers: Bruker Avance $300(75 \mathrm{MHz})$ and Bruker Avance 500 (125 MHz). The spectra were calibrated with respect to the solvent (acetone: 29.84 ppm, 206.26 ppm; chloroform: 77.16 ppm; dichloromethane: $53.84 \mathrm{ppm}$; DMSO: $39.52 \mathrm{ppm}$ ). For processing, analysis and interpretation of NMR spectra, the program TopSpin 3.2 by Bruker was used. All observed signals are singlets. Elemental analyses were carried out in the Department of Chemistry at the University of Heidelberg on the instruments vario EL and vario MICRO cube by Elementar Analysensysteme $\mathrm{GmbH}$. Infrared spectra were recorded on a Bruker Lumos instrument with a Germanium ATR-crystal. The positions of the peaks are indicated in wavenumbers $v$ in $\mathrm{cm}^{-1}$. The following abbreviations were used to describe both the intensity and profile of the signals: w (weak), m (medium), s (strong), br (broad). Mass spectra were recorded by the Mass Spectrometry Service Facility of the Organic-Chemical Department of the University of Heidelberg using the following instruments: Vacuum Generators ZAB-2F, Finnigan MAT TSQ 700, JEOL JMS-700, Bruker ICR Apex-Qe hybrid 9.4 T FT-ICR. In general the ionization method was specified. Apart from the method of ionization and the peak of the molecular ion, the base peak and characteristic fragmentation peaks with their relative intensities are reported.

\section{Syntheses}

\section{3,3'-(Ethane-1,2-diyl)bis(4,5-dimethylthiazolium)} dibromide (1a)

A Schlenk flask was charged with 3.00 equiv 4,5-dimethylthiazole $(1.00 \mathrm{~g}, 8.84 \mathrm{mmol})$ and 1.00 equiv 1,2-dibromoethane $(0.55 \mathrm{~g}, 2.95 \mathrm{mmol})$. The mixture was stirred at $115^{\circ} \mathrm{C}$ for $3 \mathrm{~d}$.
After cooling to room temperature, the resulting solid was suspended in ethanol $(2 \mathrm{~mL})$ and the mixture was filtered. The solid residue was washed with ethanol $(3 \times 2 \mathrm{~mL})$ and diethyl ether $(3 \times 3 \mathrm{~mL})$ and dried in vacuo to give the beige product $\mathbf{1 a}$ (1.05 g, $2.53 \mathrm{mmol}, 86 \%) .{ }^{1} \mathrm{H}$ NMR (400.33 MHz, DMSO- $d_{6}$, $300.0 \mathrm{~K}) \delta 9.90(\mathrm{~s}, 2 \mathrm{H}, \mathrm{NCHS}), 5.04\left(\mathrm{~s}, 4 \mathrm{H}, \mathrm{CH}_{2}\right), 2.52(\mathrm{~s}, 6 \mathrm{H}$, $\left.\mathrm{NCCH}_{3}\right), 2.47\left(\mathrm{~s}, 6 \mathrm{H}, \mathrm{SCC} H_{3}\right) \mathrm{ppm} ;{ }^{13} \mathrm{C}\left\{{ }^{1} \mathrm{H}\right\} \mathrm{NMR}(100.66$ $\left.\mathrm{MHz}, \mathrm{DMSO}-d_{6}, 295.0 \mathrm{~K}\right) \delta 157.1$ (NCHS), $141.9\left(\mathrm{NCCH}_{3}\right)$, $133.7\left(\mathrm{SCCH}_{3}\right), 50.6\left(\mathrm{CH}_{2}\right), 12.1\left(\mathrm{NCCH}_{3}\right), 11.1\left(\mathrm{SCCH}_{3}\right)$ ppm; elemental analysis calculated: $\mathrm{C}, 34.80 ; \mathrm{H}, 4.38 ; \mathrm{N}, 6.76$; found: C, 34.69; H, 4.63; N, 6.64; HRMS (ESI ${ }^{+}$, DMSO/ $\mathrm{MeOH}) m / z$ (\%): 253.0827 (100.0) $[\mathrm{M}-\mathrm{H}-2 \mathrm{Br}]^{+}, 352.9222$ (41.3), $746.9344(35.0)\left[2 \mathrm{M}\left({ }^{79} \mathrm{Br}\right)-\mathrm{Br}\right]^{+}$, calculated for $[\mathrm{M}-$ $\mathrm{H}-2 \mathrm{Br}]^{+}:$253.0833, found: 253.0827; IR (ATR) $v=3400(\mathrm{w}$, br), 3070 (s), 2970 (s), 1738 (m), 1583 (s), 1443 (s), 1405 (s), 1189 (s), 798 (s) $\mathrm{cm}^{-1} ; \mathrm{mp} 255^{\circ} \mathrm{C} \mathrm{dec}$.

\section{3,3'-(Ethane-1,2-diyl)bis(4,5-dimethylthiazolium) bis(hexafluorophosphate) (1b)}

1.00 equiv 3,3'-(ethane-1,2-diyl)bis(4,5-dimethylthiazolium) dibromide (1a, $1.50 \mathrm{~g}, 3.62 \mathrm{mmol}$ ) was dissolved in $75 \mathrm{~mL}$ $\mathrm{H}_{2} \mathrm{O}$. The solution was added slowly to aqueous $55 \%$ hexafluorophosphoric acid (3.00 equiv, $2.88 \mathrm{~g}, 10.9 \mathrm{mmol}$ ) in $50 \mathrm{~mL}$ $\mathrm{H}_{2} \mathrm{O}$. The mixture was stirred at room temperature for $3 \mathrm{~h}$. The formed precipitate was filtered and washed with water $(3 \times 25 \mathrm{~mL})$ and diethyl ether $(5 \times 20 \mathrm{~mL})$. It was dried in vacuo to give the colourless product $\mathbf{1 b}(1.50 \mathrm{~g}, 2.75 \mathrm{mmol}$, $76 \%$ ). Single crystals of salt $\mathbf{1 b}$ that were suitable for an X-ray structure analysis were obtained from acetone/diethyl ether. ${ }^{1} \mathrm{H}$ NMR (400.33 MHz, acetone- $\left.d_{6}, 295.0 \mathrm{~K}\right) \delta 9.88(\mathrm{~s}, 2 \mathrm{H}$, $\mathrm{NCHS}), 5.42\left(\mathrm{~s}, 4 \mathrm{H}, \mathrm{CH}_{2}\right), 2.68\left(\mathrm{~s}, 6 \mathrm{H}, \mathrm{NCCH}_{3}\right), 2.66(\mathrm{~s}, 6 \mathrm{H}$, $\left.\mathrm{SCCH}_{3}\right) \mathrm{ppm} ;{ }^{13} \mathrm{C}\left\{{ }^{1} \mathrm{H}\right\} \mathrm{NMR}\left(100.66 \mathrm{MHz}\right.$, acetone- $d_{6}$, $295.0 \mathrm{~K}) \delta 157.1(\mathrm{NCHS}), 143.7\left(\mathrm{NCCH}_{3}\right), 136.1\left(\mathrm{SCCH}_{3}\right)$, $52.4\left(\mathrm{CH}_{2}\right), 12.6\left(\mathrm{NCCH}_{3}\right), 11.6\left(\mathrm{SCCH}_{3}\right) \mathrm{ppm}$; elemental analysis calculated: C, 26.48; H, 3.33; N, 5.15; found: C, 26.50; H, 3.34; N, 5.37; HRMS (ESI $\left.{ }^{+}, \mathrm{CH}_{2} \mathrm{Cl}_{2} / \mathrm{MeOH}\right) \mathrm{m} / z$ (\%): 253.0828 (14.0) $\left[\mathrm{M}-\mathrm{H}-2 \mathrm{PF}_{6}\right]^{+}, 399.0548$ (100.0) $[\mathrm{M}-$ $\left.\mathrm{PF}_{6}\right]^{+}, 683.1201$ (15.7), 943.0741 (73.0) [2 $\left.\mathrm{M}-\mathrm{PF}_{6}\right]^{+}$; calculated for $\left[\mathrm{M}-\mathrm{PF}_{6}\right]^{+}: 399.0548$, found: 399.0548 ; IR (ATR) $v=$ $3132(\mathrm{w}), 1739$ (w), $1595(\mathrm{w}), 1453(\mathrm{w}), 1211(\mathrm{w}), 828(\mathrm{~s}), 740$ (w) $\mathrm{cm}^{-1} ; \mathrm{mp} 220^{\circ} \mathrm{C} \mathrm{dec}$.

\section{$\mu$-Acetato-kO,kO'- $\mu$-[3,3'-(ethane-1,2-diyl)bis(4,5- dimethylthiazol-2-ylidene)]- $\mathrm{K} C, \mathrm{~K} C^{\prime}$-dicopper(I) hexafluorophosphate (2)}

A Schlenk flask flushed with argon was charged with 3,3'(ethane-1,2-diyl)bis(4,5-dimethylthiazolium) bis(hexafluorophosphate) (1b, 0,10 g, $0.18 \mathrm{mmol}, 1.00$ equiv) and anhydrous sodium acetate ( $0.04 \mathrm{~g}, 0.42 \mathrm{mmol}, 2.30$ equiv). The reaction mixture was stirred under reduced pressure overnight. In a glove box, copper(I) acetate (0.05 g, $0.40 \mathrm{mmol}, 2.20$ equiv) 
and dichloromethane or tetrahydrofuran $(3 \mathrm{~mL})$ were added. The suspension was stirred at room temperature for $5 \mathrm{~d}$.

a) Procedure for the reaction in dichloromethane: The suspension was filtered over a frit and the solution was concentrated by reducing the solvent in vacuo to $2 \mathrm{~mL}$. Diethyl ether $(4 \mathrm{~mL})$ was added and the formed precipitate was filtered, washed with diethyl ether $(3 \times 2 \mathrm{~mL})$ and dried in vacuo to give the light beige product 2 (0.06 g, $0.10 \mathrm{mmol}, 56 \%)$.

b) Procedure for reaction in tetrahydrofuran: The solvent was removed under reduced pressure and dichloromethane $(4 \mathrm{~mL})$ was added in the glove box. The suspension was filtered over a frit and the solution was concentrated by reducing the solvent in vacuo to $2 \mathrm{~mL}$. Diethyl ether $(4 \mathrm{~mL})$ was added and the formed precipitate was filtered, washed with diethyl ether $(3 \times 2 \mathrm{~mL})$ and dried in vacuo to give the light beige product $2(0.09 \mathrm{~g}$, $0.16 \mathrm{mmol}, 86 \%) .{ }^{1} \mathrm{H}$ NMR $\left(600.24 \mathrm{MHz}, \mathrm{CD}_{2} \mathrm{Cl}_{2}, 295.0 \mathrm{~K}\right) \delta$ $4.85\left(\mathrm{~s}, 4 \mathrm{H}, \mathrm{CH}_{2}\right), 2.47$ (s, 6H, $\left.\mathrm{NCCH}_{3}\right), 2.38\left(\mathrm{~s}, 6 \mathrm{H}, \mathrm{SCCH}_{3}\right)$, 2.13 (s, 3H, $\left.H_{3} \mathrm{CCOO}\right) \mathrm{ppm} ;{ }^{13} \mathrm{C}\left\{{ }^{1} \mathrm{H}\right\}$ NMR $(150.95 \mathrm{MHz}$, $\left.\mathrm{CD}_{2} \mathrm{Cl}_{2}, 295.0 \mathrm{~K}\right) \delta 197.7(\mathrm{NCCuS}), 182.7\left(\mathrm{H}_{3} \mathrm{CCOO}\right), 141.2$ $\left(\mathrm{NCCH}_{3}\right), 133.6\left(\mathrm{SCCH}_{3}\right), 55.3\left(\mathrm{CH}_{2}\right), 22.9\left(\mathrm{H}_{3} \mathrm{CCOO}\right), 12.7$ $\left(\mathrm{NCCH}_{3}\right), 12.1\left(\mathrm{SCCH}_{3}\right) \mathrm{ppm}$; elemental analysis calculated: $\mathrm{C}$, 28.82; H, 3.28; N, 4.80; found: C, 28.70; H, 3.61; N, 4.84; HRMS (ESI $\left.{ }^{+}, \mathrm{DMSO} / \mathrm{MeOH}\right) \mathrm{m} / z$ (\%): 251.0672 (42.3) [M $\left.2 \mathrm{Cu}-\mathrm{H}-\mathrm{Oac}-\mathrm{PF}_{6}\right]^{+}, 283.0935$ (100.0) $[\mathrm{M}-2 \mathrm{Cu}-\mathrm{Oac}-$ $\left.\mathrm{PF}_{6}+\mathrm{CH}_{3} \mathrm{O}\right]^{+}, 397.0392$ (17.7), 599.0698 (69.9); calculated for $\left[\mathrm{M}-2 \mathrm{Cu}-\mathrm{Oac}-\mathrm{PF}_{6}+\mathrm{CH}_{3} \mathrm{O}\right]^{+}:$283.0949, found: 283.0935 . IR (ATR) $v=1594(\mathrm{w}), 1555(\mathrm{~m}), 1447(\mathrm{~m}), 1397(\mathrm{w}), 1328$ (w), $835(\mathrm{~s}), 691(\mathrm{~m}) \mathrm{cm}^{-1} ; \mathrm{mp} 175^{\circ} \mathrm{C} \mathrm{dec}$.

\section{Supporting Information}

\section{Supporting Information File 1}

Author contributions, details of the procedures for the kinetic measurements, and figures of NMR spectra. [http://www.beilstein-journals.org/bjoc/content/ supplementary/1860-5397-12-151-S1.pdf]

\section{Acknowledgements}

Financial support by the Ruprecht-Karls-Universität Heidelberg is gratefully acknowledged.

\section{References}

1. Kolb, H. C.; Finn, M. G.; Sharpless, K. B. Angew. Chem., Int. Ed. 2001, 40, 2004-2021.

doi:10.1002/1521-3773(20010601)40:11<2004::AID-ANIE2004>3.0.CO ;2-5

2. Hein, J. E.; Fokin, V. V. Chem. Soc. Rev. 2010, 39, 1302-1315. doi:10.1039/b904091a
3. Meldal, M.; Tornøe, C. W. Chem. Rev. 2008, 108, 2952-3015. doi: $10.1021 / \mathrm{cr} 0783479$

4. Tornøe, C. W.; Christensen, C.; Meldal, M. J. Org. Chem. 2002, 67, 3057-3064. doi:10.1021/jo011148j

5. Rostovtsev, V. V.; Green, L. G.; Fokin, V. V.; Sharpless, K. B. Angew. Chem., Int. Ed. 2002, 41, 2596-2599. doi:10.1002/1521-3773(20020715)41:14<2596::AID-ANIE2596>3.0.CO ;2-4

6. Tornøe, C. W.; Meldal, M. In Peptides: The Wave of the Future: Proceedings of the Second International and the Seventeenth American Peptide Symposium, San Diego, CA, U.S.A., June 9-14, 2001; Lebl, M.; Houghen, R. A., Eds.; Springer: Dordrecht, Netherlands, 2001; pp 263-264.

7. Tang, W.; Becker, M. L. Chem. Soc. Rev. 2014, 43, 7013-7039. doi:10.1039/C4CS00139G

8. Lutz, J.-F.; Zarafshani, Z. Adv. Drug Delivery Rev. 2008, 60, 958-970. doi:10.1016/j.addr.2008.02.004

9. Hassan, S.; Müller, T. J. J. Adv. Synth. Catal. 2015, 357, 617-666. doi:10.1002/adsc.201400904

10. Jiang, Y.; Chen, J.; Deng, C.; Suuronen, E. J.; Zhong, Z. Biomaterials 2014, 35, 4969-4985. doi:10.1016/j.biomaterials.2014.03.001

11. Schulze, B.; Schubert, U. S. Chem. Soc. Rev. 2014, 43, 2522-2571. doi:10.1039/C3CS60386E

12. Hua, Y.; Flood, A. H. Chem. Soc. Rev. 2010, 39, 1262-1271. doi:10.1039/b818033b

13. Tron, G. C.; Pirali, T.; Billington, R. A.; Canonico, P. L.; Sorba, G.; Genazzani, A. A. Med. Res. Rev. 2008, 28, 278-308. doi:10.1002/med.20107

14. Mamidyala, S. K.; Finn, M. G. Chem. Soc. Rev. 2010, 39, 1252-1261. doi:10.1039/B901969N

15. Fokin, V. V. ACS Chem. Biol. 2007, 2, 775-778. doi:10.1021/cb700254v

16. Bevilacqua, V.; King, M.; Chaumontet, M.; Nothisen, M.; Gabillet, S.; Buisson, D.; Puente, C.; Wagner, A.; Taran, F. Angew. Chem., Int. Ed. 2014, 53, 5872-5876. doi:10.1002/anie.201310671

17. Wu, P.; Fokin, V. V. Aldrichimica Acta 2007, 40, 7-17.

18. Hänni, K. D.; Leigh, D. A. Chem. Soc. Rev. 2010, 39, 1240-1251. doi:10.1039/B901974J

19. Kappe, C. O.; Van der Eycken, E. Chem. Soc. Rev. 2010, 39, 1280-1290. doi:10.1039/b901973c

20. Golas, P. L.; Matyjaszewski, K. Chem. Soc. Rev. 2010, 39, 1338-1354. doi:10.1039/b901978m

21. Evans, R. A. Aust. J. Chem. 2007, 60, 384-395. doi:10.1071/CH06457

22. Binder, W. H.; Sachsenhofer, R. Macromol. Rapid Commun. 2008, 29 , 952-981. doi:10.1002/marc.200800089

23. Meldal, M. Macromol. Rapid Commun. 2008, 29, 1016-1051. doi:10.1002/marc.200800159

24. Johnson, J. A.; Finn, M. G.; Koberstein, J. T.; Turro, N. J. Macromol. Rapid Commun. 2008, 29, 1052-1072. doi:10.1002/marc.200800208

25. Liang, L.; Astruc, D. Coord. Chem. Rev. 2011, 255, 2933-2945. doi:10.1016/j.ccr.2011.06.028

26. Fournier, D.; Hoogenboom, R.; Schubert, U. S. Chem. Soc. Rev. 2007, 36, 1369-1380. doi:10.1039/B700809K

27. Presolski, S. I.; Hong, V. P.; Finn, M. G. Copper-Catalyzed Azide-Alkyne Click Chemistry for Bioconjugation. Current Protocols in Chemical Biology; 2011; Vol. 3, pp 153-162. doi:10.1002/9780470559277.ch110148

28. El-Sagheer, A. H.; Brown, T. Chem. Soc. Rev. 2010, 39, 1388-1405. doi:10.1039/b901971p 
29. Amblard, F.; Cho, J. H.; Schinazi, R. F. Chem. Rev. 2009, 109, 4207-4220. doi:10.1021/cr9001462

30. Le Droumaguet, C.; Wang, C.; Wang, Q. Chem. Soc. Rev. 2010, 39, 1233-1239. doi:10.1039/B901975H

31. Arseneault, M.; Wafer, C.; Morin, J.-F. Molecules 2015, 20, 9263. doi:10.3390/molecules20059263

32. Rodionov, V. O.; Fokin, V. V.; Finn, M. G. Angew. Chem. 2005, 117, 2250-2255. doi:10.1002/ange.200461496

33. Berg, R.; Straub, B. F. Beilstein J. Org. Chem. 2013, 9, 2715-2750. doi:10.3762/bjoc.9.308

34. Worrell, B. T.; Malik, J. A.; Fokin, V. V. Science 2013, 340, 457-460. doi:10.1126/science.1229506

35. Schoffelen, S.; Meldal, M. Modern Alkyne Chemistry; Wiley-VCH: Weinheim, Germany, 2014; pp 113-142.

36. Jin, L.; Tolentino, D. R.; Melaimi, M.; Bertrand, G. Sci. Adv. 2015, 1, e1500304. doi:10.1126/sciadv.1500304

37. Makarem, A.; Berg, R.; Rominger, F.; Straub, B. F. Angew. Chem., Int. Ed. 2015, 54, 7431-7435. doi:10.1002/anie.201502368

38. Shao, C.; Cheng, G.; Su, D.; Xu, J.; Wang, X.; Hu, Y. Adv. Synth. Catal. 2010, 352, 1587-1592. doi:10.1002/adsc.200900768

39. Gonda, Z.; Novák, Z. Dalton Trans. 2010, 39, 726-729. doi:10.1039/b920790m

40. Berg, R.; Straub, J.; Schreiner, E.; Mader, S.; Rominger, F.; Straub, B. F. Adv. Synth. Catal. 2012, 354, 3445-3450. doi:10.1002/adsc.201200734

41. Bessel, M. Rationales Design von Katalysatoren für die Kupfer-katalysierte Azid-Alkin-Cycloaddition. Ph.D. Thesis, Ruprecht-Karls-Universität Heidelberg, Germany, 2010.

42. Farrugia, L. J. J. Appl. Crystallogr. 2012, 45, 849-854. doi:10.1107/S0021889812029111

43. Persistence of Vision Raytracer POV-Ray, Version 3.7; , http://www.povray.org.

44. Dewick, P. M. Essentials of Organic Chemistry: For Students of Pharmacy, Medicinal Chemistry and Biological Chemistry; John Wiley \& Sons: Hoboken, NJ, U.S.A., 2006.

\section{License and Terms}

This is an Open Access article under the terms of the Creative Commons Attribution License (http://creativecommons.org/licenses/by/2.0), which permits unrestricted use, distribution, and reproduction in any medium, provided the original work is properly cited.

The license is subject to the Beilstein Journal of Organic Chemistry terms and conditions: (http://www.beilstein-journals.org/bjoc)

The definitive version of this article is the electronic one which can be found at: doi:10.3762/bjoc.12.151 